\title{
Peculiarities of financing investment infrastructure projects in Ukraine
}

\author{
Nataliia Savina ${ }^{1}$, Nataliia Kovshun ${ }^{1 *}$, Alla Zhemba ${ }^{1}$, Alisa Ventsuryk ${ }^{1}$, and Oksana \\ Kliukha $^{1}$ \\ ${ }^{1}$ National University of Water and Environmental Engineering, 33028, Rivne, Ukraine
}

\begin{abstract}
The purpose of the article is to show the role of international financial organizations in financing the development of the transportation network of Ukraine. It is shown the necessity of implementation of infrastructure projects for the development of the state economy and increase of its competitiveness. The structure of sources of financing in the development of highways is shown and the gradual reduction of the share of investments at the expense of the State budget and the insignificant role of public and private partnership in the transport sphere are revealed. The cooperation of Ukraine with international financial organizations: the International Bank of Reconstruction and Development, the European Bank of Reconstruction and Development, and the European Investment Bank in the implementation of infrastructure projects have been studied. A retrospective analysis of the available loan agreements was performed. The expected positive consequences of international investment for the transport sector of Ukraine and the economy as a whole have been identified. Information is given on real investment infrastructure projects with the participation of international financial institutions and the financial conditions of their implementation. The shifts in the arrangement of highways of Ukraine at the expense of international investments are listed.
\end{abstract}

\section{Introduction}

To overcome the difficult economic situation, Ukraine needs to modernize the road network, which can be done through the implementation of investment infrastructure projects. Given the unsatisfactory financial condition of the transport sector in the short term, attracting investment funds will help stabilize the road sector by providing the necessary funds for road maintenance. In the medium and long term - economic growth and competitiveness, by strengthening ties between regions and improving transit corridors [1]. Modernization of the road network will enhance economic activity by reducing travel times and reducing transportation costs between major centers in Ukraine and their regional trading partners.

At the same time, improved road infrastructure will increase productive investment in the territorial communities that benefit from investment infrastructure projects and create

\footnotetext{
* Corresponding author: nata-an@ukr.net
} 
jobs for their residents, which in turn will increase household incomes and consumption levels, as well as reduce poverty. It should also be borne in mind that the development of transport requires not only the construction of roads but also involves solving problems such as reducing road congestion, environmental protection, traffic safety, etc. [1].

\section{Analysis of recent approaches and publications}

The resumption of Ukraine's economy and growth of its competitiveness largely depends on the efficiency of the transport system. This relationship has been studied by scientists from different countries and using different approaches [2]. India's experience has shown that there are long-term interrelations between transport infrastructure and economic development, where economic development being the main factor in most cases [3]. The paper [4]describes the concept of transport infrastructure in Latvia as an important part of the state transport system. The impact of infrastructure development on the economic progress of India and China also confirms the importance of building a transport system, including the use of foreign investment [5] . In general, it is introduced the impact of road development on economic growth in the new EU member states [6].

\section{Results}

In order to restore and develop public roads of national importance for their integration into the European transport system and increase the level of traffic safety, speed, comfort, and efficiency of transportation, the Cabinet of Ministers of Ukraine in 2013 developed and approved the State Targeted Economic Program for Public Roads use for 2013-2018.

It is state support and its quality that determine the development of the transport industry [7]. This program was not implemented in full due to underfunding in 2015-2016. Targeted funding sources were canceled, and the planned expenditures for road development in the general fund of the state budget were usually underfunded by the Treasury. As a result, in 2015-2016, the construction of highways was actually stopped, the volume of work on the current average repair was ten times lower than the norm, the pothole was eliminated late and not on all roads. In 2016-2017, due to increased funding, repair and construction work on public roads were significantly intensified, but the lists of facilities were formed not on the basis of this Program, but by separate orders of the Cabinet of Ministers of Ukraine. This unstable state of transport financing was caused by political instability in Ukraine. It should be noted that political and institutional interference in economic processes must be balanced and justified. Attracting foreign, regional, or private investments in the implementation of infrastructure projects depends on government strategies $[8,9]$.

The projected amount of funding for the State Targeted Economic Program for the Development of Public Roads of State Importance for 2018-2022 is UAH 372.3 billion, of which $67.5 \%$ should be financed from the State Budget.

During the implementation of the program, the amount of funding increases significantly over the years from 30.0 billion in 2018 to $97.5 \%$ in 2022 (Table 1).

It should be noted that significant changes in funding sources during the implementation of this program. If in 2018, the amount of funding from the State budget in 2018 is $87.6 \%$, and for other sources, including investors' funds account for $12.4 \%$, then in $2022-48.9 \%$ and $47.3 \%$, respectively. At the same time, it is not typical for Ukraine to attract private investors, although public-private partnerships for individual investment projects are the most rational [10]. 
Table 1. Financing of the State Target Economic Program of highways development of public use of the state value for 2018-2022.

\begin{tabular}{|c|c|c|c|c|c|c|}
\hline \multirow{2}{*}{ Sources of funding } & \multirow{2}{*}{$\begin{array}{l}\text { Volume of } \\
\text { financing, } \\
\text { million } \\
\text { hryvnias }\end{array}$} & \multicolumn{5}{|c|}{ Including by years, million hryvnias } \\
\hline & & 2018 & 2019 & 2020 & 2021 & 2022 \\
\hline State budget, including: & 251300 & 26328 & 35984 & 95203 & 46132 & 47653 \\
\hline $\begin{array}{l}\text { Special fund of the state } \\
\text { budget }\end{array}$ & 212424 & 20025 & 35217 & 63395 & 46133 & 47653 \\
\hline $\begin{array}{l}\text { General fund of the state } \\
\text { budget }\end{array}$ & 38877 & 6302 & 766 & 31808 & & \\
\hline $\begin{array}{l}\text { Funds of international } \\
\text { financial organizations }\end{array}$ & 20256 & 3722 & 4463 & 4440 & 3910 & 3719 \\
\hline $\begin{array}{l}\text { Other sources, including } \\
\text { investors' funds }\end{array}$ & 100781 & & 514 & 18043 & 36051 & 46172 \\
\hline Total & 372337 & 30050 & 40962 & 117687 & 86094 & 97545 \\
\hline
\end{tabular}

Financing schemes for infrastructure projects implemented with the participation of international financial institutions are receiving increasing attention around the world. At the same time, there is a defined range of issues that the government must address in order to obtain the necessary investment [11]. For many years, Ukraine has been actively and effectively cooperating with international financial organizations: the International Bank for Reconstruction and Development (IBRD), the European Bank for Reconstruction and Development (EBRD), and the European Investment Bank (EIB). Their activities, among other things, aim to assist in the implementation of investment infrastructure projects (overhaul, reconstruction, and construction of roads, institutional development), which is carried out through long-term lending and consulting services the implementation of projects.

Implementation of investment infrastructure projects, with the participation of the IBRD, EBRD, and EIB, will cause the following economic effect:

- reducing the number of accidents related to unsatisfactory road conditions;

- reduction of the negative impact of the road transport complex on the environment;

- strengthening of roadsides will allow to eliminate dust formation, will improve drainage from the carriageway and from the road, will reduce erosion of soils and pollution of open reservoirs and ground waters;

- reduction of annual operating costs of road transport, taking into account the loss of passengers as a result of travel,

- reduction of annual investment in road transport;

- reduction of annual unproductive loss of working time of passengers on the road;

- reduction of consumption of motor fuels,

The reduction of annual costs for current repairs of highways resulted from the improvement of transport and operational condition, which can be directed to current repairs and maintenance of other highways [12-14]. According to the cooperation with international financial organizations, in 2018 works and services were financed in the amount of UAH 3.7 billion, in 2019 - UAH 4.3 billion. Institutional development includes the provision of consulting services, training, and supply of equipment to strengthen the traffic management system and improve the maintenance of roads following an international practice. 
The purpose of the implementation projects of investment infrastructure projects with the participation of the IBRD is the rehabilitation of the international highway M-03 (Kyiv - Kharkiv - Dovzhanskyi checkpoint), improving road safety (elimination of places of concentration of accidents) and institutional development. With the participation of the EBRD, the M-06 (Kyiv-Chop) highway is being restored and the financing of the road sector is being reformed. With the joint participation of the EBRD and the EIB, the reconstruction of the last section of the M06 road, the improvement of Ukraine's road infrastructure, and the promotion of further reform in Ukraine's road sector (Table 2).

Table 2. International highways of Ukraine, on which investment infrastructure projects are implemented.

\begin{tabular}{|c|l|c|l|}
\hline $\begin{array}{c}\text { Index \& } \\
\text { № roads }\end{array}$ & \multicolumn{1}{|c|}{ Names of highways } & $\begin{array}{c}\text { Length, } \\
\text { km. }\end{array}$ & \multicolumn{1}{|c|}{ Comments } \\
\hline M-03 & $\begin{array}{l}\text { Kyiv - Kharkiv - Dovzhanskyi (in } \\
\text { the city of Rostov-on-Don); } \\
\text { entrances: to Kharkiv International } \\
\text { Airport, to Kharkiv, to Poltava }\end{array}$ & 937,3 & $\begin{array}{l}\text { Is essentially important for } \\
\text { Ukraine's integration with the EU } \\
\text { road network as a potential transit } \\
\text { corridor of national and } \\
\text { international importance }\end{array}$ \\
\hline \multirow{3}{\text{M-06}}{} & $\begin{array}{l}\text { Kyiv - Chop (in the city of } \\
\text { Budapest via Lviv, Mukachevo } \\
\text { an Uzhorod); entrances: to }\end{array}$ & $\begin{array}{l}\text { Zhytomyr, to Novohrad- } \\
\text { Volynskyi, to Lviv, to Uzhhorod, } \\
\text { western entrance to Rivne, } \\
\text { southern approach to Rivne }\end{array}$ & $\begin{array}{l}\text { on the territory of Ukraine, which } \\
\text { passes through the territory of } \\
\text { Kyiv, Zhytomyr, Rivne, Lviv and } \\
\text { Zakarpattia regions and is part of } \\
\text { the European transport corridors } \\
\text { №3 and №5 }\end{array}$ \\
\hline
\end{tabular}

The first loan agreement was concluded in December 2000 with the EBRD. Currently, 9 credit agreements have been concluded between Ukraine and international financial organizations, including 4 credit agreements with the EBRD (total value of EUR 825.0 million), 2 credit agreements with the EIB (total value of EUR 750.0 million), and 3 loan agreements with the IBRD (total value of $\$ 1,187.0$ million). Information on the implementation of investment infrastructure projects with the participation of international financial institutions and the relevant financial conditions is provided below (Table 3, Table 4, Table 5, Table 6).

Table 3. Information on the implementation of investment infrastructure projects with the participation of the IBRD.

\begin{tabular}{|c|c|}
\hline Name & Value \\
\hline Allocated funds, million USD & 1187,8 \\
\hline Disbursed funds, million USD & 853,3 \\
\hline Funds mastered,\% & 71,8 \\
\hline Concluded contracts & 67 \\
\hline including: construction work & 25 \\
\hline consulting services & 42 \\
\hline Deadline for projects & $2009-2021$ \\
\hline Number and status of projects & 3 \\
\hline $\begin{array}{c}\text { Put into operation (repaired/built) roads (km.) And man-made } \\
\text { structures (pieces) }\end{array}$ & $259,1 \mathrm{~km} . / 53 \mathrm{pc}$. \\
\hline Loan maturity & $2009-2038$ \\
\hline
\end{tabular}


The beneficiary of the agreements is the Ministry of Finance of Ukraine or the State Agency of Motor Roads of Ukraine. The source of repayment is the state budget.

Table 4. Financial conditions for the implementation of investment infrastructure projects with the participation of the IBRD.

\begin{tabular}{|c|c|c|c|}
\hline \multirow{2}{*}{ Name } & \multicolumn{3}{|c|}{ Projects } \\
\hline & RSIP I & RSIP II & RSDP \\
\hline $\begin{array}{l}\text { One-time sales } \\
\text { commission }\end{array}$ & $0,25 \%$ & $0,25 \%$ & $0,25 \%$ \\
\hline $\begin{array}{l}\text { Sub-loan agreement } \\
\text { commission }\end{array}$ & $0,50 \%$ & & \\
\hline Reservation fee & & & $0,25 \%$ \\
\hline Interest rate & $\begin{array}{l}\text { LIBOR + variable } \\
\text { margin }\end{array}$ & $\begin{array}{c}\text { LIBOR + } \\
\text { variable margin }\end{array}$ & $\begin{array}{l}\text { LIBOR + variable } \\
\text { margin }\end{array}$ \\
\hline $\begin{array}{l}\text { The repayment } \\
\text { schedule of the } \\
\text { principal amount of the } \\
\text { loan }\end{array}$ & $\begin{array}{c}\text { May } 15 \text { and } \\
\text { November } 15 \text {, starting } \\
\text { from } 11 / 15 / 14\end{array}$ & $\begin{array}{c}\text { April } 15 \text { and } \\
\text { October } 15, \text { starting } \\
\text { from } 15.10 .18\end{array}$ & $\begin{array}{l}\text { February } 15 \text { and } \\
\text { August } 15 \text {, starting } \\
\text { from 15.02.2022 }\end{array}$ \\
\hline The term of the loan & $2009-2038$ & $2012-2029$ & $2016-2032$ \\
\hline
\end{tabular}

Table 5. Information on the implementation of investment infrastructure projects with the participation of the EBRD and the EIB.

\begin{tabular}{|l|c|}
\hline \multicolumn{1}{|c|}{ Name } & Value \\
\hline Allocated funds, EUR million & 1475,0 \\
\hline including European Bank for Reconstruction and Development & 825,0 \\
\hline European Investment Bank & 650,0 \\
\hline Funds disbursed, EUR million & 1167,8 \\
\hline including European Bank for Reconstruction and Development & 754,9 \\
\hline European Investment Bank & 412,9 \\
\hline Funds mastered,\% & 79,2 \\
\hline including European Bank for Reconstruction and Development & 91,5 \\
\hline European Investment Bank & 63,5 \\
\hline Number of concluded contracts & 37 \\
\hline including construction work & 22 \\
\hline consulting services & 15 \\
\hline Deadline for projects & 2000 - 2021 \\
\hline Number and status of projects & 4 \\
\hline $\begin{array}{l}\text { Put into operation (repaired/built) roads (km.) And man-made } \\
\text { structures (bridges, overpasses, pedestrians...) }\end{array}$ & $987.7 \mathrm{~km} . / 169$ artificial \\
\hline Loan maturity & 2000 - 2031 \\
\hline
\end{tabular}

The main achievements in the implementation of investment infrastructure projects with the participation of IBRD:

- overhaul and reconstruction of $259.1 \mathrm{~km}$ were performed. roads, of which $82.7 \mathrm{~km}$ of roads were brought from the II to the I technical category; 
- the strengthening of the existing pavement by the technology of cold recycling was carried out. For the device of the top layer of a covering the crushed stone-mastic asphalt concrete made with the use of modern additives that will allow overcoming problems of a track in the summer period is used. Additional strengthening of asphalt concrete layers on lanes of heavy transport is provided by a special reinforcing grid;

- to improve winter maintenance and increase road safety, 6 road meteorological stations were installed, 53 man-made structures were built, of which: 32 man-made pedestrian crossings at different levels and 21 bridges, overpasses, and cattle runs; bringing the M-03 to the highway standard, which was a direct contribution to a significant reduction in the number of accidents in the area between Boryspil and Lubny from 248 per year before the project to 10 per year of project closure.

Table 6. Financial conditions for the implementation of investment infrastructure projects with the participation of the EBRD and the EIB.

\begin{tabular}{|c|c|c|c|c|}
\hline \multirow{3}{*}{ Name } & \multicolumn{4}{|c|}{ Projects } \\
\hline & \multicolumn{2}{|c|}{ № 3} & \multicolumn{2}{|c|}{ № 4} \\
\hline & EBRD & EIB & EBRD & EIB \\
\hline $\begin{array}{l}\text { One-time } \\
\text { commission }\end{array}$ & $1,00 \%$ & 500,0 тис. євро & $1,00 \%$ & $0,25 \%$ \\
\hline Commitment fee & $0,50 \%$ & $0,10 \%$ & $0,50 \%$ & $0,10 \%$ \\
\hline $\begin{array}{l}\text { Subcredit } \\
\text { Commission }\end{array}$ & $0,50 \%$ & $0,50 \%$ & $0,50 \%$ & $0,50 \%$ \\
\hline Interest rate & EURIBOR $+1 \%$ & $\begin{array}{c}\text { EURIBOR + } \\
0,55 \%\end{array}$ & EURIBOR+1\% & EURIBOR $+0,75 \%$ \\
\hline $\begin{array}{l}\text { The term of the } \\
\text { loan }\end{array}$ & $2006-2022$ & $2007-2031$ & $2010-2021$ & $2011-2020$ \\
\hline
\end{tabular}

It is planned to achieve:

- Rehabilitation and improvement of traffic safety in selected sections of M-03,

- building institutional capacity to facilitate the implementation of reforms in the field of maintenance.

- implementation of road safety and network management system.

Main achievements in the implementation of investment infrastructure projects with the participation of the EBRD and the EIB:

- $2006-224 \mathrm{~km}$ of roads were put into operation. 52 bridges and overpasses were repaired and/or renovated, $\{18\}-181 \mathrm{~km}$ were commissioned in 2009. 26 bridges and 25 overpasses were repaired and/or renovated,

- 2013 - improvement of road conditions on $341.9 \mathrm{~km}$ of repaired road M-06 KyivChop;

- overhaul of roads on general roads $240.8 \mathrm{~km}$ long. 66 artificial structures were repaired;

It is planned to achieve:

- overhaul of roads with a total length of $142 \mathrm{~km}$ with bringing $22 \mathrm{~km}$ to the I technical category.

- repair of artificial structures (17) and construction of new artificial structures (45).

Implementation of investment infrastructure projects should be subordinated to the task of structural restructuring of the transport sector, aimed at ensuring balanced and harmonious development of all parts of the complex, to renew the production capacity, increase the efficiency of its use. For the further development of the transport industry, it is necessary to concentrate investments on the introduction of high-performance and the latest innovations and information technologies, renewal, and modernization of fixed assets and infrastructure. 


\section{Conclusions}

Ensuring a favorable investment climate remains a matter of strategic importance, the implementation of which depends on the effectiveness of economic growth measures in Ukraine, the effectiveness of investment projects, the possibility of modernization of the transport sector. The formation of a favorable investment climate should take place both at the macro and regional levels, optimizing the whole set of political, legal, economic, social, environmental, organizational, informational, industrial and regional specific factors.

\section{References}

1. Freeman, P. N. (2009). Ten years of World Bank action in transport: evaluation. Journal of infrastructure systems, 15(4), 297-304.

2. Candemir, Y., \& Çelebi, D. (2017). An inquiry into the analysis of the Transport \& Logistics Sectors' Role in Economic Development. Transportation research procedia, 25, 4692-4707.

3. Maparu, T. S., \& Mazumder, T. N. (2017). Transport infrastructure, economic development and urbanization in India (1990-2011): Is there any causal relationship?. Transportation research part A: policy and practice, 100, 319-336.

4. Skorobogatova, O., \& Kuzmina-Merlino, I. (2017). Transport infrastructure development performance. Procedia Engineering, 178, 319-329.

5. Kim, M. J., \& Nangia, R. (2010). Infrastructure development in India and China: A comparative analysis. In Physical infrastructure development: Balancing the growth, equity, and environmental imperatives (pp. 97-139). Palgrave Macmillan, New York.

6. Rokicki, B., \& Stępniak, M. (2018). Major transport infrastructure investment and regional economic development-An accessibility-based approach. Journal of Transport Geography, 72, 36-49.

7. Kyriacou, A. P., Muinelo-Gallo, L., \& Roca-Sagalés, O. (2019). The efficiency of transport infrastructure investment and the role of government quality: An empirical analysis. Transport Policy, 74, 93-102.

8. Cerra, V., Cuevas, A., Goes, C., Karpowicz, I., Matheson, T., Samake, I., \& Vtyurina, S. (2017). Determinants of Infrastructure and Its Financing. Emerging Economy Studies, 3(2), 113-126.

9. Tei, A., \& Ferrari, C. (2018). PPIs and transport infrastructure: Evidence from Latin America and the Caribbean. Journal of Transport Geography, 71, 204-212.

10. Makarov, I., \& Plotnikov, V. (2018). Public-private partnership as a financial instrument for the transport infrastructure modernizing. In MATEC Web of Conferences (Vol. 170, p. 05012). EDP Sciences.

11. Kumaraswamy, M., \& Zhang, X. (2001). Governmental role in BOT-led infrastructure development. International Journal of Project Management, 19(4), 195-205.

12. Kvach, Y., Piatka, N., \& Koval, V. (2020). Management of sustainable entrepreneurship adaptation to tax changes in environmental investment. Baltic Journal of Economic Studies, 6(5), 96-105. https://doi.org/10.30525/2256-0742/2020-6-5-96-105

13. Arsawan, I. W. E., Koval, V., Duginets, G., Kalinin, O., \& Korostova, I. (2021). The impact of green innovation on environmental performance of SMEs in an emerging economy. In E3S Web of Conferences, 255, 01012.

14. Tsimoshynska, O., Koval, M., Kryshtal, H., Filipishyna, L., Arsawan, W. E., Koval, V. (2021). Investing in road construction infrastructure projects under public-private partnership in the form of concession. Naukovyi Visnyk Natsionalnoho Hirnychoho Universytetu, 2, 184-192. 